\title{
The Predictive Power of the Self-efficacy Beliefs of Physical Education Candidate Teachers on their Attitudes towards the Assessment and Evaluation in Education
}

\author{
Yaprak Kalemoğlu Varol \\ Department of Physical Education and Sport, Aksaray University, Turkey
}

Copyright $(2016$ by authors, all rights reserved. Authors agree that this article remains permanently open access under the terms of the Creative Commons Attribution License 4.0 International License

\begin{abstract}
The aim of the research is to examine relationship between self-efficacy beliefs and attitudes for assessment and evaluation of physical education candidate teachers. In this research, the relational model has been used. Study group consists of 86 women (48\%), 93 men (52\%) and total 179 physical education teacher candidates $\left(M_{\mathrm{age}}=22.17\right.$, $\mathrm{SD}=1.61$ ) who are studying at physical education department in three universities. As data collection tool "Self-Efficacy Perceptions of Candidate Teachers at Assessment and Evaluation in Education" and "Attitude toward Educational Measurement Inventory" has been used. In the analysis, addition to descriptive statistics, inferential statistics such as correlation and regression analysis has been used. It has determined that "self-efficacy based-skill" belief for assessment and evaluation in this research has a moderate effect size towards attitude for assessment and evaluation. Also, it has been shown that variables constituting self-efficacy belief subscale for assessment and evaluation have explained $10 \%$ of total variance for assessment and evaluation of attitude in education. Besides, it has been found that attitude and self-efficacy beliefs of teacher candidates for assessment and evaluation in education were high level.
\end{abstract}

Keywords Self-efficacy, Attitude, Assessment and Evaluation in Education, Physical Education Candidate Teacher

\section{Introduction}

Education which is a topic emphasized in shaping future of countries' future and in the development of societies, as expressed by Ertürk (1972) [1] is a process of forming the desired direction of change in the behavior of individuals. This process covers teaching objectives and activities and assessment steps. Assessment and evaluation stage is the important stage of education system [2]. In other words, objectives of teaching what extent to be realized and what the objectives are not realized are detected with assessment and evaluation activities. Therefore, these activities can be considered as an important part and integral of education process. However, how targets in education and teaching are determined as well as, how content of course is selected and organized as well, as long they are not conducted by teachers who have the targets and understandings, it is impossible to take the expected results from education (3). Proper and successful fulfillment of assessment and evaluation is only possible with qualification of teachers in this field. Gawith (1995) has stated that even though people have the qualification to do any work, if not confidence, there is a possibility not to do the job. Also Bandura has expressed that success is not only dependent on having the skills, success requires to use skill with confidence effectively at the same time (as cited in Kurbanoğlu, 2004) [4]. Starting from this information, it can be considered that assessment and evaluation of students' success in educational institutions together with teacher's qualification, an important factor that is to manifest skills possessed self-efficacy relation to these activities.

Self-efficacy belief is not related to how effective on individual's qualification and is a concept that his/her belief for his/her skills. This belief determines individuals how feel in a specific subject, what they think and how they motivate themselves and how they behave [5]. Kotaman (2008) [6] has specified that this belief affects whether act or not for an attitude on task, the continuity in behavior, their motivation and ultimately their performance.

Besides, undergraduate period of teachers whose professional lives, knowledge and skills will implement these activities in educational institutions is especially important. Because Dellinger et all. (2008) [7] expressed that the reason of teachers' self-efficacy beliefs based on their education while Woolfolk and Spero (2005) [8] stated that their efficacy perceptions develop greatly in their undergraduate period. Therefore, determining candidate teachers' self-efficacy related to assessment and evaluation 
activities especially in undergraduate period and exercising in this aspect are important in order to minimize from the point of their future lives which problems may occur. When the exercises for candidate teachers' self-efficacy related to determine assessment and evaluation have been examined, Çelik and Arslan (2012) [9] stated that physical education candidate teachers' general efficacy perceptions have been identified, candidate teachers who weren't satisfied with courses for assessment and evaluation during their undergraduate period have been efficacy perception at low level in the result of research. On study by Arslan, Erturan-İlker ve Demirhan (2013) [10] has been found that general efficacy perception of physical education candidate teachers' relation to assessment and evaluation has at low level. From the study with faculty of education's candidate teachers by Şahin and Uysal (2013) [11] has been found that candidate teachers' self-efficacy perceptions have a moderate level. While study conducted with Turkish and class teachers have been resulted that they perceive often themselves inadequate or partially adequate related to assessment and evaluation tool and approaches [12]. The study conducted with fourth class students in the faculty of education by Evin-Gencel, Özbaşı (2013) [13] and Pektaş (2010) [14] have found that candidate teachers perceive themselves at moderate level related to assessment and evaluation field.

In the literature, it is expressed that self-efficacy belief for a particular field affects individual's attitude and behaviors related to that field [15]. Therefore, their attitudes of having assessment and evaluation activities together with candidate teachers' self-efficacy beliefs are also especially important. Because, as Yurdugül and Aşkar (2008) [16] indicated that one of main factors success of students at particular field or shaping of a teaching program design for learning products is "attitude" variable. Attitudes shape human behavior in different ways, determine the participation in daily activities and shape their behavior as a condition of acceptance or release [17]. Alkharusi, Kazemve Al-Musawi (2011) [18] also stated that teachers who have positive attitude for assessment and evaluation could make more reliable evaluation.

With movement of relation between attitude and self-efficacy belief related to assessment and evaluation may not be only sufficient in candidate teachers, besides it could be expressed that effect on assessment and evaluation practices may be for assessment and evaluation. As Yaşar stated (2014) [19] that teachers' equipped with only their field is not sufficient but also have efficacy in assessment and evaluation in education, and they should have positive attitude for assessment and evaluation to have this efficacy. And also researchers $[20 ; 21]$ stated that on the basis of negative attitudes for assessment and evaluation, courses which were taken on the undergraduate period have not met needs and originated from math-weighted and hard course could be considered. Any research hasn't been founded determining assessment and evaluation of candidate teachers' in the literature. However, if physical education candidate teachers have negative attitudes for assessment and evaluation with determination of low self-efficacy beliefs, the reason of these could be investigated and thus more concrete suggestion may be made. With realization of determining situation especially during candidate teacher period, the troubled situation that may occur will be provided to be avoided in the future. As Çakır et all. (2006) [22] stated, effectiveness and efficacy of teacher education programs could be evaluated with candidate teachers' positive attitudes and also their self-efficacy perceptions at high level.

In the education system, on behalf of benefit from physical education courses which have a significant share from the point of education purpose realization at the highest level, it is extremely important teachers' whose knowledge and skills related assessment and evaluation conduct course. For this reason, it has been thought to be useful that determination of attitudes, self-efficacy beliefs and relationship between them for assessment and evaluation considered as an effect on these skills during candidate teachers. From this point of view, determination of self-efficacy together with attitudes towards assessment and evaluation of physical education candidate teachers, self-efficacy attitude towards this field for assessment and evaluation and strength procedures are aimed in this study.

\section{Method}

\section{Research model}

In this study, the relational research model has been used. In this study, relationship between physical education candidate teachers' attitudes for assessment and evaluation in education with their self-efficacy perceptions for mentioned activities has been analyzed.

\section{Research group}

Research group consists of 179 candidate teachers $\left(M_{\mathrm{age}}=22.17, \mathrm{SD}=1.61\right)$ who study at Physical Education and Sport Teacher department in three different universities (Aksaray University, Niğde University and Erciyes University) in 2013-2014 academic year. 86 (48\%) of research group are women and while 93 of $(52 \%)$ are men $\left(N_{\text {grade- }}=116 ; N_{\text {grade- }}=63\right)$.

In institutions which give education to physical education teachers, a common program is used whose implementation obligatory, prepared by the Higher Education Authority. According to this program, education period consists of 8 terms (4 years). Within this program, "Assessment and Evaluation" course is taken at 4th semester. To reach the most effective results and provide full compliance for purpose of study, study group has been selected from third and fourth class candidate teachers.

\section{Data Collection Tools}

As data collection tool "Self-Efficacy Scale for Assessment and Evaluation in Education and Attitude Inventory for Assessment and Evaluation in Education" was used. 
Self-Efficacy Scale for Assessment and Evaluation in Education: The scale developed by Kılınç (2011) [23] in order to determine the self-efficacy for assessment and evaluation of physical education teacher candidates consists of 23 items and two factors. The factors were named as " knowledge based self-efficacy" and "self-efficacy based on skills". All items in the scale consist of positive expressions. Scale items are five likert type and (5) completely agree, (4) agree, (3) undecided, (2) disagree and (1) never disagree. Cronbach's alpha coefficient is calculated as for the entire scale .96, for "knowledge-based self-efficacy" that is the first sub-dimension .93 and for "self-efficacy based on skills" that is the second sub-dimension 0.95 . Internal consistency coefficient was calculated again for this study and as a result of analysis, cronbach's alpha values were identified as; .72 for total scale, .69 for the first sub-dimension and .70 for the second sub-dimension.

Attitude Inventory for Assessment and Evaluation in Education: Attitude Inventory for Assessment and Evaluation in Education developed by Bryant and Barnes (1997) was adapted to Turkish by Ozan and Köse (2013) [24]. The scale, as the original form, consists of three factors and 31 items as 13 items for relevance, 10 items for affective and 8 items for course. 24 of the items in the scale are positive and 17 of them are negative. Scales items are five likert type as (5) completely agree and (1) never disagree. The lowest score is 31 and the highest score is 155 that can be obtained from the scale. All high scores can be taken from the scale and subscale refers to high-level positions. The scale showed high internal consistency and test-retest reliability. Cronbach's alpha coefficients of internal consistency; .88 for the lower interest factor, .83 for affective subscales of course for sub-factors are calculated as .86 and .92 for the entire scale. The test-retest reliability coefficient of $.74-.80$ is for the full range and scale is .78 . Confirmatory factor analysis high cohesion values obtained results showed that the scale of the three factors structure of validate $(\mathrm{RMSEA}=0.070$, $\mathrm{NFI}=0.94, \mathrm{NNF} \mathrm{U}=0.96, \mathrm{CFI}=0.96, \mathrm{SRM}=0.076, \mathrm{GF}=$ 0.90 and AGF of 0.87).

\section{Data Analysis}

Distributions of data were examined before analysis. In the study, the distribution was analyzed before the data analysis. It was found that the data was consistent with distrubition by the Lilliefors and Kolmogorov-Smirnov test $(p>05)$. Histogram graphic and normal distribution curve were determined by Skewness $(+1$ and -1$)$ and Kurtosis $(+2$ and -2 ) and further analysis was performed accordingly. First of all, in the research, arithmetic mean values of the items that are in each subscale were calculated and a score for that factor was determined. Analyses were carried out for this factor scores. In the analysis of data, Pearson Moments Multiplication Correlation Coefficient technique was used in order to determine the relationship with statistics (number, percent, arithmetic mean and standard deviation). However, the education of self-efficacy beliefs for measurement and evaluation, measurement and power to determine the attitude of the procedure for evaluating multiple linear regression analysis was performed. 0.05 significance level of 0.01 was used for the interpretation of the data. The data were analyzed with SPSS 18 program.

\section{Findings}

Mean and standard deviation values related to attitudes towards assessment and evaluation of education of physical education teachers and self-efficacy beliefs are given in Table 1.

Table 1. Scores related to attitudes and self-efficacy beliefs for measurement and evaluation

\begin{tabular}{cccc}
\hline $\begin{array}{c}\text { Assessment and evaluation in } \\
\text { education }\end{array}$ & $\mathrm{n}$ & $M$ & SD \\
\hline Knowledge based self-efficacy & & 35.38 & 7.911 \\
Skill based self-efficacy & & 45.21 & 9.182 \\
Self-efficacy belief Total & & 80.59 & 15.931 \\
\hline Relevance & \multirow{2}{*}{179} & 44.40 & 6.581 \\
Affective & & 30.27 & 5.665 \\
Course & & 25.73 & 4.557 \\
Attitude Total & & 100.42 & 12.694 \\
\hline
\end{tabular}

When Table 1 is examined, it was seen that the physical education teacher candidates' assessment and evaluation of self-efficacy beliefs $\left(M_{\text {self-efficacy }}=80.59\right)$ and the level of attitudes toward assessment and evaluation in education $\left(M_{\text {attitude }}=100.42\right)$ were high level.

\section{The Relationship between Self Efficacy Belief and Attitude towards assessment and evaluation in education}

Physical education teachers' attitudes towards the education of candidate assessment and evaluation have tried to determine the relationship between self-efficacy and results of the analysis are given in Table 2.

Table 2. The relationship between self-efficacy belief and attitude towards assessment and evaluation in education

\begin{tabular}{cccccc}
\hline VARIABLES & A & B & C & D & E \\
\hline $\begin{array}{c}\text { Knowledge based } \\
\text { self-efficacy (A) }\end{array}$ & 1 & & & & \\
\hline $\begin{array}{c}\text { Skill based } \\
\text { self-efficacy (B) }\end{array}$ & $.736^{* *}$ & 1 & & & \\
\hline Relevance (C) & $.328^{* *}$ & $.317^{* *}$ & 1 & & \\
\hline Affective (D) & -.057 & -.013 & $.435^{* *}$ & 1 & \\
\hline Course (E) & $.393^{* *}$ & $.401^{* *}$ & $.462^{* *}$ & .093 & 1 \\
\hline Mean & 35.38 & 45.21 & 44.40 & 30.27 & 25.73 \\
\hline $\begin{array}{c}\text { Standard } \\
\text { Deviations }\end{array}$ & 7.911 & 9.182 & 6.581 & 5.665 & 4.557 \\
\hline $\mathrm{p}<0.01^{* *}$ & & & & &
\end{tabular}

When Table 2 is examined, it was seen that positive and moderate relationship between knowledge based self-efficacy with relevance $(\mathrm{r}=0.328, \mathrm{p}<0.01)$ and course $(\mathrm{r}=0.393, \mathrm{p}<0.01)$ dimensions.

Also it was found that positive and moderate correlation between skill based self-efficacy with relevance ( $\mathrm{r}=0.317$, $\mathrm{p}<0.01)$ and course $(\mathrm{r}=0.401, \mathrm{p}<0.01)$ dimensions. According to this result, it can be said that self-efficacy increases, attitude level increases. 
Table 3. Regression analysis for predictive power of attitudes towards assessment and evaluation in education

\begin{tabular}{|c|c|c|c|c|c|c|c|}
\hline Variables & B & $\begin{array}{l}\text { Standard } \\
\text { Error }\end{array}$ & B & $\mathrm{t}$ & $\mathrm{p}$ & Dual r & Partial r \\
\hline Constant & 80.598 & 4.714 & & 17.098 & $000 * *$ & & \\
\hline $\begin{array}{c}\text { Knowledge based } \\
\text { self-efficacy }\end{array}$ & 0.133 & 0.170 & 0.083 & 0.785 & .433 & .261 & .059 \\
\hline $\begin{array}{l}\text { Skill based } \\
\text { self-efficacy }\end{array}$ & 0.334 & 0.146 & 0.242 & 2.282 & $.024 *$ & .303 & .170 \\
\hline $\mathrm{R}=0.308$ & \multicolumn{2}{|c|}{$\mathrm{R}^{2}=0.95$} & & & & & \\
\hline $\mathrm{F}=9.226$ & \multicolumn{2}{|c|}{$\mathrm{p}=.000$} & & & & & \\
\hline
\end{tabular}

When the findings presented in Table 3 were examined, it was seen that the prediction equation $\left(\mathrm{R}^{2}=.095 ; \mathrm{F}=9.226\right.$, $\mathrm{p}<.01)$ for the self-efficacy scale on the attitude toward the assessment and evaluation in education was of great importance. The variables constituting the self-efficacy sub-dimension expressed $102 \%$ of the total variance at assessment and evaluation attitudes in education. The relative significance level of the predictive variables on the attitude towards assessment and evaluation in education according to the standardized regression parameter ( $(B)$ was in the order of skill based self-efficacy and knowledge based self-efficacy. In line with all these findings, it was identified that the assessment and evaluation self-efficacy dimensions had a moderate effect on the attitudes towards the assessment and evaluation in education.

\section{Discussion and Conclusion}

In the study, physical education candidate teachers' self-efficacy beliefs of measurement and evaluation in education were found to be at a high level (Table 1). There is no direct study to support this finding. However, findings do not coincide with the results of the education of teachers as a result of many studies to determine the efficacy evaluation and assessment $[9 ; 10 ; 11 ; 12 ; 13 ; 14)$. Being different from the properties of difference samples between research findings, graduated field type from high school, attitude towards the students' course, which is not included in the study as the teaching methods used in the course latent variables are thought to cause the differences in the findings. The attitude levels for measurement and evaluation in education, which is evidence obtained from the study of physical education teachers has been realized with the same high level (Table 1). It was not seen study which was examine attitude towards assessment and evaluation of teacher candidates. However, even if a limited number of studies available, there are also studies in which attitude levels are determined $(25 ; 26)$. In the studies made by Çalışkan and Yazıcı (2013) [25] with social studies teachers, it was concluded that teachers have positive attitude towards assessment and evaluation. Erdoğdu (2010) [26] stated that the graduates of the Faculty of Education and teachers that had assessment and evaluation courses during two periods also have positive attitude towards assessment and evaluation. It can be considered as a good result that situated in the education of teachers in the study group, a positive attitude towards the assessment and evaluation, high in self-efficacy beliefs. Because, as Erdoğan (2010) [26] expressed that, effective and efficient may be the education of teachers with assessment and evaluation of proficiency testing and evaluation depends on the attitude towards positive.

Along with the attitude scale subscales for measuring and evaluation on the relationship between self-efficacy scale subscales (Table 2), self-efficacy, knowledge-based ( $\mathrm{r}=$ $0.328, \mathrm{p}<0.01)$ and self-efficacy based on skills $(\mathrm{p}=0.317, \mathrm{p}$ $<0.01$ ) with size, a positive correlation between attitudes towards assessment and evaluation subscale of relevance and of course the size of the scale was found to be a moderate correlation. Along with this increase in self-efficacy beliefs for measurement and evaluation results based on the attitude level for the measurement and evaluation can be said that this is the rise. However, measurement and evaluation of self-efficacy scale in three dimensions based on the information on the positive relationship between self-efficacy and self-efficacy was determined based on skills and a high level of relations. It can be said that as teacher candidates' knowledge based self-efficacy towards measurement and assessment, skill based self-efficacy level also increases.

Measurement of self-efficacy skills-based education for mid-level measurement and evaluation in education, research and evaluation, it was determined that the attitude towards having an effect size (Table 3). In addition, measurement and evaluation of self-efficacy, impact on attitudes towards the measurement and evaluation in education is described by a rate of $10 \%$. There is no direct study to support this finding. However, findings showed similar results with studies that examined the relationship between self-efficacy and attitudes. Ipek and Acuner (2011) [15] by the teacher of the study with candidates, teacher candidates' attitudes towards educational technology of the variance in computer self-efficacy beliefs are seen to be explained only 3\%. Usta and Korkmaz (2010) [27] class and social studies teachers in their study with student teachers with computer proficiency levels increase, the increase in positive attitudes towards the use of technology in education has been observed. Hence the attitude or self-efficacy beliefs would also increase the other is an increase in the positive direction, the other in the event of a reduction would decrease. 
In addition, the attitude or the other will increase self-efficacy beliefs of the measures to be taken to improve, the other one can be said to reduce the drop of a variable factor. Therefore, the educational environment must be taken into consideration when developing this relationship. However, this study contributes to the field of thought to bring only be from a selected group of prospective teachers from three universities and study groups prevents generalization of the results to be relatively small. Physical education teachers' education in the assessment and evaluation of research towards self-efficacy beliefs, in the context of being the first study to measure and to determine the predictive power of their position to assess, it is thought that it will shed light on the future studies that will be carried out. Therefore, there is a need for similar studies in different sample areas. It is thought that such studies will be beneficial in terms of providing physical education teachers candidates' attitudes and self-efficacy beliefs to assessment and evaluation in education.

\section{REFERENCES}

[1] Ertürk, S. (1972). Eğitimde Program Geliştirme, Ankara, Yelkentepe Yayınları.

[2] Çoştu, B. (2012). Ölçme ve Değerlendirmeyle İlgili Temel Kavramlar, Eğitimde Ölçme ve Değerlendirme. (Edt: M. Küçük \& Y. Geçit). Ankara: Nobel.

[3] Ciğerdelen, T., Aslan, F. (2011). An Investigation to Communication Skills of Kocaeli University Physical Education and Sport Department Students'. Van University Journal of Faculty of Education, Special Issue, 96-114.

[4] Kurbanoğlu, S.S. (2004). Self-Efficacy Belief and Its Importance for Information Professionals. Information World, 5(2), 137-152.

[5] Akkoyunlu, B., Orhan, F., \&Umay, A. (2005). A Study on Developing Teacher Self Efficacy Scale for Computer Teachers. Hacettepe University Journal of Education, 29, $1-8$.

[6] Kotaman, H. (2008). Self-Efficacy Belief and Enhancement of Learning Performance. Journal of Uludag University Faculty of Education, XXI (1), 111-133.

[7] Dellinger, A.B., Bobbettb, J.J., Olivier, D.F., Ellet, C.D. (2008). Measuring Teacher Self-Efficacy Beliefs: Development and Use of the TEBS-Self. Teaching and Teacher Education, 24, 751-766.http://dx.doi.org/10.1016/j .tate. 2007.02 .010

[8] Woolfolk-Hoy, A., Spero, R. (2005). Changes in teacher Efficacy during the Early Years of Teaching: A Comparison of Four Measures. Teaching and Teacher Education. 21, 343-356.

[9] Çelik, Z., Arslan, Y. (2012). Determination of Prospective Physical Education Teachers' Measurement and Evaluation Common Competency Perceptions. Selcuk University Journal of Physical Education and Sport Science. 14(2),
$223-232$

[10] Arslan, Y., Erturan-İlker, G., Demirhan, G. (2013). The Impact of a Developed Measurement and Evaluation Development Program on Pre-service Physical Education Teachers' Perceptions Related to Measurement and Evaluation. Educational Sciences: Theory \& Practice, 13 (2), 1107-1124.

[11] Şahin, M., Uysal, İ. (2013). Analysis of Pre-service Teachers' Self-Efficacy Perceptions on Measurement and Evaluation. Bartın University Journal of Faculty of Education, 2 (2), 190-207. http://dx.doi.org/10.14686/2013 21987

[12] Kilmen, S., Akın-Kösterelioğlu, M., Kösterelioğlu, İ. (2007). Öğretmen Adaylarının Ölçme ve Değerlendirme Araç ve Yaklaşımlarına İlișkin Algıları. Abant Izzet Baysal University Journal of Faculty of Education, 7 (1), 129-140.

[13] Evin-Gencel, İ., Özbaşı, D. (2013). Investigating Prospective Teachers' Perceived Levels of Competence towards Measurement and Evaluation. Elementary Education Online, 12 (1), 190-201.

[14] Pektaş, S. (2010). The Analysis of Teacher Candidates Competency Perceptions on Measurement and Assessment, Master of Science Dissertation, Bolu, Abant Izzet Baysal University, Institute of Social Science.

[15] İpek, C., Acuner, H. Y. (2011). Primary Pre-service Teachers' Computer Self-Efficacy Beliefs and Attitudes toward Educational Technologies. Ahi Evran University Journal of Faculty of Education, 12(2), 23-40.

[16] Yurdugül, H., Akar, P. (2008). An Investigation of the Factorial Structures of Pupils' Attitude towards Technology (PATT): A Turkish Sample. Elementary Education Online, 7(2), 288-309.

[17] Rikard, L., Banville, D. (2006). High school student attitudes about physical education. Sport, Education and Society, 11 (4), 385-400. http://dx.doi.org/10.1080/1357332 0600924882

[18] Alkharusi, H., Kazem, A.M., Al-Musawai, A. (2011). Knowledge, Skills and Attitudes of Preservice and Inservice Teachers in Educational Measurement. Asia-Pasific Journal of Teacher Education, 39 (2), 113-123. http://dx.doi.org/10. 1080/1359866X.2011.560649

[19] Yaşar, M. (2014). Development of an Attitude Scale for an Educational Measurement and Evaluation Course. Journal of Educational Sciences Research, 4 (1), 259-279.

[20] Alkharusi, H. (2009). Correlates of Teacher Education Students' Academic Performance in an Educational Measurement Course. Internal Journal of Learning, 16, $1-15$.

[21] Kottke, J.L. (2000). Mathematical Profiency, Statistics Knowledge, Attitudes toward Statistics, and Measurement Course Performance. The College Student Journal, 34, 334-347.

[22] Çakır, Ö, Kan, A., Sünbül, Ö. (2006). The Evaluation of the Teaching Certificate Program and the Masters Program without Thesis with respect to Students' Attitudes and Self-efficacy. Mersin University Journal of the Faculty of Education, 2 (1), 36-47.

[23] Kılınç, M. (2011). A Perceptual Scale for Measurement and 
Evaluation of Prospective Teachers Self-Efficacy in Education. Journal of Kirsehir Education Faculty. 12(4), 81-93.

[24] Ozan, C., Köse, E. (2013). Adaptation of Attitudes toward Educational Measurement Inventory (ATEMI) to Turkish. E-International Journal of Educational Research. 4(2), $29-47$.

[25] Çalışkan, H., Yazıcı, K. (2013). Developing an Attitude Scale Assessment and Evaluation and Analyzing of Social Studies Teachers Attitude Levels in terms of Several Variables. International Journal of Human Sciences, 10 (1),
$398-415$

[26] Erdoğdu, M.Y. (2010). A Study on Examining Teachers' Measurement and Evaluation Attitudes by means of Different Variables, International Conference on New Trends in Education and Their Implications, 11-13 November, Antalya, Turkey.

[27] Usta, E., Korkmaz, Ö. (2010). Pre-Service Teachers' Computer Competencies, Perception of Technology Use and Attitudes toward Teaching Career. International Journal of Human Sciences, 7(1), 1335-1349. 